\title{
Bacterial Endocarditis 1956-1965: Analysis of Clinical Features and Treatment in Relation to Prognosis and Mortality
}

\author{
E. A. SHINEBOURNE, C. M. CRIPPS, G. W. HAYWARD, AND R. A. SHOOTER \\ From the Departments of Cardiology and Bacteriology, St. Bartholomew's Hospital, London E.C.I
}

This paper reviews the pattern of bacterial endocarditis over the ten-year period from 1956 to 1965 in a hospital to which patients are referred from other centres. The series is, therefore, unrepresentative as it includes many patients with resistant organisms. The symptomatology, and physical and pathological findings, are discussed and related to the prognosis. Patients with subacute bacterial endocarditis are distinguished from those with acute endocarditis and those with endocarditis complicating major systemic disease.

Throughout the series antibiotic therapy has been controlled by in vitro laboratory tests. The aim has been to maintain for six weeks a serum level of antibiotic that is bactericidal to the infecting organism, isolation of which, therefore, becomes of prime importance. Despite considerable care, however, a proportion of blood cultures remains sterile, and the reasons for this are considered.

\section{SUBJECTS AND METHODS}

All patients diagnosed as having bacterial endocarditis between January 1956 and December 1965 were reviewed, and only cases where the diagnosis was disproved at necropsy were discarded. This gave a total of 93 patients who have been divided into three groups for analysis (Table I). The main features of cases included in Group III are shown in Table II, and will be considered in detail elsewhere.

Bacteriological Methods. Blood cultures were taken by a member of the Bacteriology Department, and a multiple culture technique was employed, including the preparation of pour plates and provision for anaerobic growth. Organisms from positive cultures were identified, and arbitrary treatment was started as soon as the diagnosis was confirmed by another positive blood culture. Bacteriological examination continued with tube titrations against penicillin and other antibiotics or anti-

Received February 7, 1969. biotic combinations until a satisfactory bactericidal result was obtained. The patient's treatment was then adjusted to a dosage expected to produce at least these levels in the serum. In the majority of cases antibiotics were given by intermittent intramuscular injection, but where high concentrations of penicillin were needed massive doses (100 mega units per day) were given by continuous intravenous infusion. After 48 hours on a given regimen a serum sample was taken, selecting a time in intermittent therapy where the antibiotic level was at its lowest. In the earlier part of the series, the antibiotic content of this sample was assayed against a standard organism. Latterly, assessment was made by titration against the organism isolated from the individual patient, and treatment was considered satisfactory when, at least, a 1 in 4 dilution was bactericidal. This serum level was maintained for six weeks.

\section{RESULTS}

Age and Sex Incidence. There is an over-all male to female incidence of $2 \cdot 2: 1$. The age distribution of the whole series (Fig. 1) reaches a maximum over the fifth to seventh decades while that of Group I shows a steady rise to the seventh decade.

TABLE I

CLASSIFICATION OF PATIENTS WITH BACTERIAL ENDOCARDITIS

\begin{tabular}{cc|c|c}
\hline & No. & Per cent \\
\hline Group I: & $\begin{array}{l}\text { Cases of subacute bacterial endo- } \\
\text { carditis proven by blood culture or } \\
\text { finding of bacterial vegetations on }\end{array}$ & 63 & 68 \\
Group II: $\begin{array}{l}\text { Cart valves at necropsy of subacute bacterial endo- } \\
\text { carditis diagnosed on clinical } \\
\text { grounds, in which blood cultures }\end{array}$ & 15 & 16 \\
$\begin{array}{l}\text { were sterile and no post-mortem } \\
\text { findings were available }\end{array}$ & 16 \\
Group III: Cases of acute bacterial endocar- \\
$\begin{array}{l}\text { ditis and atypical cases where pre- } \\
\text { sence of bacterial vegetations was } \\
\text { incidental to other major systemic } \\
\text { disease or to cardiac surgery }\end{array}$
\end{tabular}


TABLE II

CLINICAL DATA OF PATIENTS WITH ACUTE BACTERIAL ENDOCARDITIS OR ENDOCARDITIS COMPLICATING MAJOR SYSTEMIC DISEASE

\begin{tabular}{|c|c|c|c|c|c|c|}
\hline $\begin{array}{l}\text { Case } \\
\text { No. }\end{array}$ & Sex & $\begin{array}{l}\text { Age } \\
\text { (yr.) }\end{array}$ & Clinical diagnosis & Blood cultures & $\begin{array}{l}\text { Outcome of } \\
\text { endocarditis }\end{array}$ & $\begin{array}{l}\text { Additional necropsy } \\
\text { findings }\end{array}$ \\
\hline 1 & $\mathbf{M}$ & 59 & Chronic bronchitis; staph. pneumoniae & Staph. aureus & Died 1/52 & Acute bact. endocard. \\
\hline 2 & $\mathbf{M}$ & 60 & Diabetes mellitus; staph. pneumoniae & Negative & Died 1/52 & Lung abscess; acute \\
\hline 3 & $\mathbf{M}$ & 62 & Urethral stricture; post-op. staph. & Not done & Died 1/52 & Acute bact. endocard. \\
\hline $\begin{array}{l}4 \\
5 \\
6\end{array}$ & $\begin{array}{l}\mathbf{M} \\
\mathbf{M}\end{array}$ & $\begin{array}{l}65 \\
49 \\
41\end{array}$ & $\begin{array}{l}\text { Staph. pneumoniae; bacterial endocarditis } \\
\text { Aortic valve replacement } 1 \text { year previously } \\
10 \text { days after mitral valvotomy; subacute }\end{array}$ & $\begin{array}{l}\text { Staph. aureus } \\
\text { Negative } \\
\text { Staph. albus }\end{array}$ & $\begin{array}{l}\text { Alive } \\
\text { Sudden death } \\
\text { Alive }\end{array}$ & Saddle embolus* \\
\hline 7 & $\mathbf{F}$ & 63 & Hepatic cirrhosis; porta-caval shunt & Not done & Died 1 day after & Acute bact. endocard. \\
\hline 8 & $\mathbf{F}$ & 48 & Hepatic cirrhosis; aortic incompetence; & Non-haemolytic & Died 6/12 & Liver failure; infection \\
\hline 9 & $\mathbf{F}$ & 15 & Acute leukaemia, on steroids; acute bact. & Staph. aureus & Died $2 / 12$ & $\begin{array}{l}\text { Healed vegetations on } \\
\text { valves }\end{array}$ \\
\hline 10 & $\mathbf{M}$ & 47 & $\begin{array}{l}\text { Acute on chronic lymphatic leukaemia; } \\
\text { subacute bact. endocard. diagnosed on }\end{array}$ & Negative & Died 2/12 & Not done \\
\hline $\begin{array}{l}11 \\
12\end{array}$ & $\begin{array}{l}\text { F } \\
\mathbf{M}\end{array}$ & $\begin{array}{l}76 \\
49\end{array}$ & $\begin{array}{l}\text { Carcinoma of stomach } \\
\text { Disseminated lupus erythematosus, on } \\
\text { steroids; meningitis }\end{array}$ & $\begin{array}{l}\text { Not done } \\
\text { Not done }\end{array}$ & $\begin{array}{l}\text { Died } 1 / 52 \\
\text { Died on day of } \\
\text { admission }\end{array}$ & $\begin{array}{l}\text { Acute bact. endocard. } \\
\text { Pneumococcal menin- } \\
\text { gitis; acute bact. }\end{array}$ \\
\hline 13 & $\mathbf{M}$ & 54 & Thyrotoxicosis, on thiouracil; neutropenia; & Negative & Alive & \\
\hline 14 & $\mathbf{F}$ & 76 & Fractured femur; coronary infarction & Not done & Died 11 days after & Acute bact. endocard. \\
\hline 15 & $\mathbf{F}$ & 4 wks. & Patent ductus arteriosus; heart failure & Not done & $\begin{array}{l}\text { Died on day of } \\
\text { admission }\end{array}$ & Acute bact. endocard. \\
\hline
\end{tabular}

* Fungal elements seen on valve, probably candida.

Underlying Heart Disease. The aetiology of the underlying heart lesion is shown in Table III and indicates a preponderance of rheumatic heart disease in Groups I and II (those with proven or probable subacute bacterial endocarditis), while Group III patients (with acute or atypical endocarditis) frequently had no underlying cardiac abnormality. Of the 55 patients with rheumatic heart disease, 43

TABLE III

NATURE OF UNDERLYING CARDIAC ABNORMALITY

\begin{tabular}{l|c|c|c|c}
\hline Heart disease & $\begin{array}{c}\text { Over-all } \\
(\%)\end{array}$ & $\begin{array}{c}\text { Group I } \\
(\%)\end{array}$ & $\begin{array}{c}\text { Group II } \\
(\%)\end{array}$ & $\begin{array}{c}\text { Group III } \\
(\%)\end{array}$ \\
\hline $\begin{array}{l}\text { Rheumatic } \\
\text { Congenital }\end{array}$ & 59 & 63 & 67 & 33 \\
$\begin{array}{l}\text { Arteriosclerotic } \\
\text { None previously } \\
\text { suspected }\end{array}$ & 16 & 14 & 33 & 12 \\
\hline
\end{tabular}

TABLE IV

DIAGNOSIS IN 55 PATIENTS WITH RHEUMATIC HEART DISEASE AND SUBACUTE BACTERIAL ENDOCARDITIS

\begin{tabular}{l|r}
\hline \multicolumn{1}{c|}{ Diagnosis } & No. \\
\hline Mitral incompetence & 13 \\
Mitral stenosis and incompetence & 7 \\
Dominant mitral stenosis & 3 \\
Aortic value disease & 9 \\
Multiple valve lesions & 23 \\
\hline
\end{tabular}

(78\%) had some degree of mitral incompetence and 3 had dominant mitral stenosis (Table IV). Aortic stenosis and ventricular septal defect were the most common lesions in those patients with congenital heart disease, and one patient had Fallot's tetralogy (Table V). Three elderly patients developed infection on valves, with nodular arteriosclerotic changes. In one patient infection was related to a dissecting

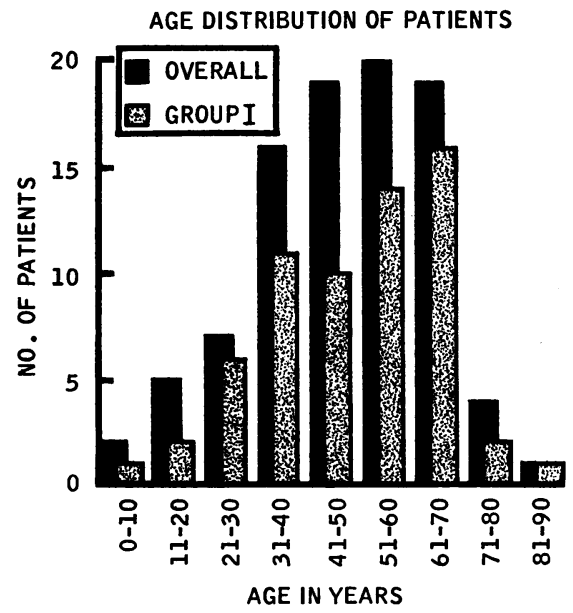

Fig. 1.-Age distribution of patients for the whole series and for Group I. 
TABLE V

DIAGNOSIS IN 15 PATIENTS WITH CONGENITAL HEART DISEASE AND
SUBACUTE BACTERIAL ENDOCARDITIS

\begin{tabular}{l|c}
\hline \multicolumn{1}{c|}{ Diagnosis } & No. \\
\hline Ventricular septal defect & 5 \\
Aortic stenosis & 5 \\
Patent ductus arteriosus & 2 \\
Fallot's tetralogy & 1 \\
Bicuspid aortic valve & 1 \\
Pulmonary stenosis & 1 \\
\hline
\end{tabular}

TABLE VI

PRESENTING SYMPTOMS

\begin{tabular}{l|c}
\multicolumn{1}{c|}{ Symptom } & Per cent \\
\hline Fever & 82 \\
Toxaemia & 73 \\
Weight loss & 43 \\
Embolic episodes & 43 \\
New cardiac symptoms & 31 \\
Joint pains & 15 \\
Pallor & 13 \\
Gastro-intestinal symptoms & 10 \\
Recurrent fever with symptomless intervals & 8 \\
\hline
\end{tabular}

aneurysm and in another to an old myocardial infarction. Two patients with previously normal hearts developed organic tricuspid incompetence during their illness.

Presenting Symptoms and Physical Findings. An analysis of the presenting symptoms is given in Table VI. Fever, manifest by sweating, chills, shivering, or rigors, occurred in 82 per cent of all cases, while recurrent fevers with symptomless intervals were a feature in 8 per cent. Toxaemic symptoms of malaise, tiredness, weakness, anorexia, and generalized aches and pains were also common. Table VII gives the findings on physical examination for the whole series, and those features with which patients presented are separated from those developing during the course of the illness. There are no major differences between the groups, but splenomegaly and clubbing are found less frequently in Group III (splenomegaly $20 \%$, clubbing

TABLE VII

PHYSICAL FINDINGS IN 93 PATIENTS WITH BACTERIAL ENDOCARDITIS

\begin{tabular}{l|c|c|c}
\hline \multicolumn{1}{c|}{ Finding } & $\begin{array}{c}\text { Presenting } \\
\text { when first } \\
\text { seen }\end{array}$ & $\begin{array}{c}\text { Developing } \\
\text { during } \\
\text { disease }\end{array}$ & Total \\
\hline Splenomegaly & 35 & 5 & $40(43 \%)$ \\
Hepatomegaly & 28 & 1 & $29(31 \%)$ \\
Clubbing & 23 & 5 & $28(30 \%)$ \\
Heart failure & 19 & 9 & $28(30 \%)$ \\
Splinter haemorrhages & 18 & 7 & $25(27 \%)$ \\
Petechiae & 9 & 7 & $16(17 \%)$ \\
Osler's nodes & 9 & 3 & $12(13 \%)$ \\
\hline
\end{tabular}

TABLE VIII

RESULTS OF BLOOD CULTURES

\begin{tabular}{l|c|c|c|c}
\hline & $\begin{array}{c}\text { Positive } \\
\text { cultures }\end{array}$ & $\begin{array}{c}\text { Negative } \\
\text { cultures }\end{array}$ & $\begin{array}{c}\text { No } \\
\text { cultures }\end{array}$ & $\begin{array}{c}\% \text { Negative } \\
\text { cult ures }\end{array}$ \\
\hline Group I & 56 & 4 & 3 & 6 \\
Group II & 0 & 13 & 2 & 100 \\
Group III & 5 & 4 & 6 & 44 \\
Over-all & 61 & 21 & 11 & 26 \\
\hline
\end{tabular}

* When blood cultures were taken.

7\%). An equal incidence of systemic emboli was found before diagnosis and during the illness, and the limbs or brain were commonly affected. Coronary emboli caused electrocardiographic changes in 7 patients.

Bacteriology, Source of Infection, and Treatment. The frequency of positive blood cultures is shown in Table VIII and the organisms isolated in Table IX. Streptococci were responsible for the majority of cases, but there was a rise in the number of nonhaemolytic and micro-aerophilic streptococci, many of which were resistant to penicillin. Of the 64 organisms isolated, 40 were sensitive to penicillin, though, in some cases, high dosage and the use of probenecid were needed to obtain bactericidal serum levels. In the remaining cases, combinations of antibiotics were used, most commonly penicillin and streptomycin, but combinations of penicillin with ampicillin, cephaloridine, or erythromycin were also used. Triple combinations of penicillin and streptomycin with erythromycin or ampicillin were needed in four cases, and in one, penicillin and neomycin had to be given (Havard, Garrod, and Waterworth, 1959).

Twenty-five patients (34\%) had received or were recorded as requiring dental treatment, and a streptococcus showing $\alpha$ or $\gamma$ haemolysis was isolated from 21. Respiratory infections acted as a focus of infection in other patients, but in 35 per cent no precipitating cause could be found.

TABLE IX

INFECTING ORGANISMS

\begin{tabular}{l|c|c|c}
\hline \multicolumn{1}{c|}{ Organism } & Group I & Group III & Over-all \\
\cline { 2 - 3 } Streptococci & 25 & 0 & 25 \\
Viridans & 1 & 0 & 1 \\
Haemolytic & 11 & 1 & 12 \\
Non-haemolytic & 6 & 0 & 6 \\
Enterococci & 10 & 0 & 10 \\
Micro-aerophilic & 1 & 0 & 1 \\
Anaerobic & 0 & 1 & 1 \\
Staphylococci & 2 & 5 & 7 \\
Albus & 0 & 1 & 1 \\
Aureus & 0 & 1 & \\
Streptococcus pneumoniae & & & \\
Fungus (histological & diagnosis) & &
\end{tabular}


Haematuria. In 78 of the 84 patients $(93 \%)$ in whom urine microscopy was performed, microscopical haematuria was found, often on more than one occasion. Of the six patients with no haematuria, 3 suffered from acute bacterial endocarditis. Microscopy was performed on a centrifuged deposit of fresh urine. The presence of haematuria is thus a highly significant feature of the disease, and its absence makes the diagnosis unlikely.

Electrocardiographic Features. When the diagnosis was made, 90 per cent of the patients were in sinus rhythm and 10 per cent were in atrial fibrillation. Pathological $Q$ waves with $S T$ and $T$ wave changes developed in 6 patients during the illness, and were thought to represent myocardial infarction following coronary emboli. Two patients developed intermittent bundle-branch block patterns, but no patients showed heart block or a significant change in the $P-R$ interval.

Mortality and Cause of Death. The mortality for the series as a whole is 31 per cent at 6 months and 40 per cent at 2 years (Fig. 2), but this is adversely weighted by patients in Group III who died from acute endocarditis, malignant, or other systemic disease. The mortality of patients with bacteriologically proven subacute bacterial endocarditis (Group I) is 25 per cent at 6 months and 32 per cent at 2 years (Fig. 2). Eleven patients received no treatment for their bacterial endocarditis either because they died within a few hours of admission or because the diagnosis was not made in life. If these patients are excluded, the 6-month mortality for the series becomes 22 per cent and for Group I 19 per cent.

Relating mortality to age (Fig. 3 and 4), the overall prognosis is worse at the extremes of age, but in Group I patients under 40 years, the prognosis is excellent. Table $\mathrm{X}$ gives the mortality related to the underlying heart disease, and in Group I shows a better prognosis in congenital than in rheumatic heart disease.

The major contributory factors to the deaths of the patients are given in Table XI. In Group I, emboli,

TABLE $X$

MORTALITY OF PATIENTS WITH SUBACUTE BACTERIAL ENDOCARDITIS (GROUP I) RELATED TO CARDIAC LESION

\begin{tabular}{l|c|c}
\hline \multicolumn{1}{c|}{ Lesion } & Number & $\begin{array}{c}\text { Mortality } \\
\text { at 6 months }\end{array}$ \\
\hline Rheumatic & 40 & 14 \\
Congenital & 9 & 0 \\
Other & 5 & 0 \\
None previously suspected & 9 & 2 \\
\hline
\end{tabular}

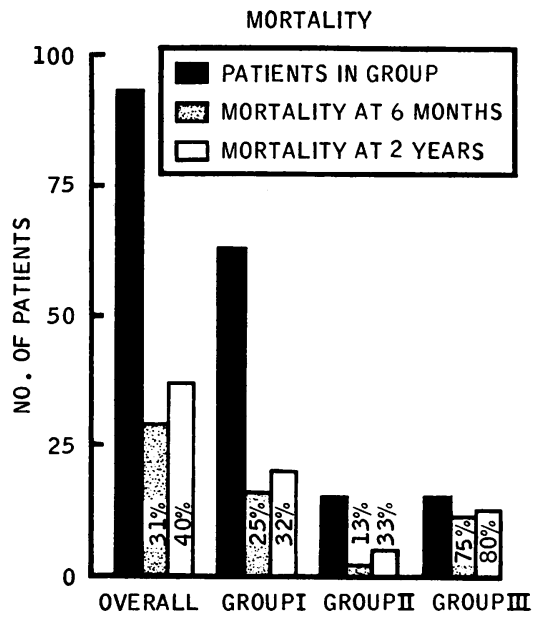

Fig. 2.-Mortalities at 6 months and at 2 years for the whole series and for the individual groups.

valve destruction, and heart failure secondary to myocardial damage were more frequent than uncontrolled infection. In the older age-group, preexisting myocardial disease from coronary arteriosclerosis contributed to the mortality.
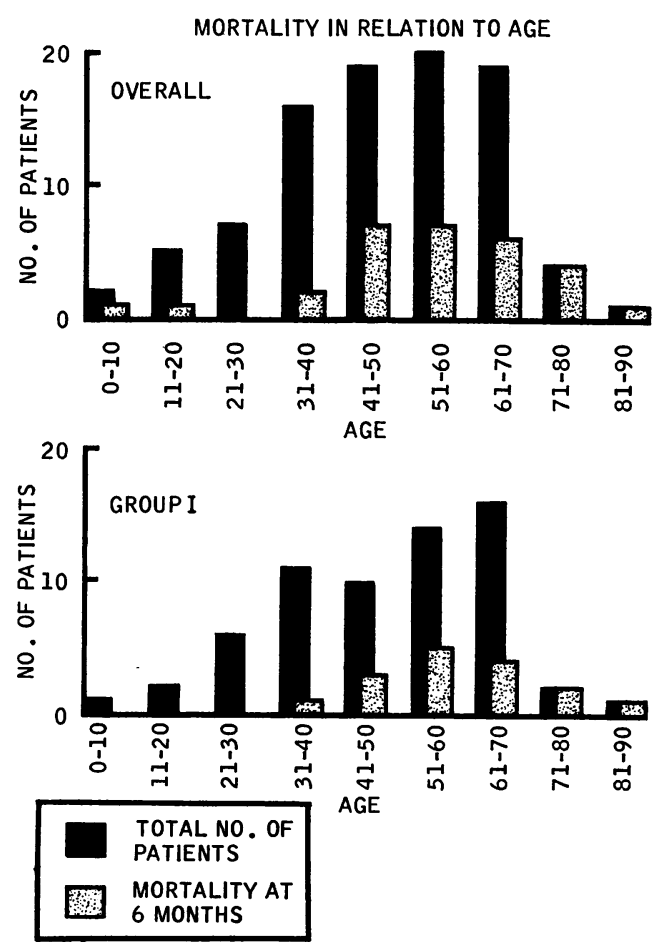

Fig. 3 and 4.-Mortalities in relation to age for the whole series, and for patients in Group I. 
TABLE XI

MAJOR CONTRIBUTORY FACTORS TO MORTALITY WHERE KNOWN

\begin{tabular}{l|c|c|c|c}
\hline & Group I & Group II & Group III & Over-all \\
\cline { 2 - 3 } $\begin{array}{c}\text { Total deaths } \\
\text { in group }\end{array}$ & 20 & 5 & 12 & 37 \\
$\begin{array}{c}\text { Uncontrolled infec- } \\
\text { tion \{untreated } \\
\text { treated }\end{array}$ & 5 & 0 & 6 & 11 \\
$\begin{array}{c}\text { Gross valvar } \\
\text { incompetence }\end{array}$ & 7 & 0 & 3 & 4 \\
$\begin{array}{c}\text { Coronary embolus } \\
\text { or infarct }\end{array}$ & 6 & 3 & 4 & 14 \\
$\begin{array}{c}\text { Systemic or pul- } \\
\text { monary embolus }\end{array}$ & 6 & 1 & 1 & 8 \\
$\begin{array}{c}\text { Uraemia } \\
\text { Other non-cardiac } \\
\text { causes }\end{array}$ & 2 & 0 & 1 & 8 \\
\hline
\end{tabular}

No significant correlation was shown between the duration of symptoms before treatment and mortality (Fig. 5), nor was there a correlation between the initial white cell count, haemoglobin, or erythrocyte sedimentation rate and mortality.

\section{Discussion}

In surveys of bacterial endocarditis the criteria on which cases are diagnosed vary as does the type of patient seen. The value of comparing this series with others is also limited, as many patients with organisms that have failed to respond to treatment elsewhere are included, making the series unrepresentative. Group I includes cases where the clinical diagnosis was confirmed by positive blood culture or by necropsy. The 15 patients in Group II had negative blood cultures, but the clinical diagnosis was made on the evidence of chronic infection, with a change in cardiac murmurs or recurrent emboli. A distinction has also been made between patients with acute and subacute bacterial endocarditis, or where the disease is a complication of other major pathology (Group III).

The bacteriological techniques used are more elaborate than some of those in general use, as we

\section{DURATION OF SYMPTOMS IN RELATION TO MORTALITY}

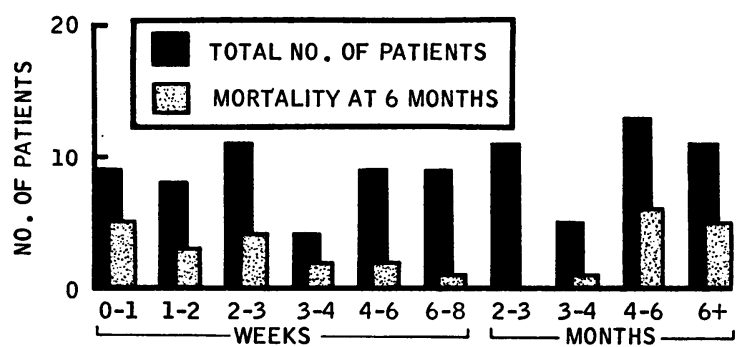

FIG. 5.-Mortality for the whole series in relation to duration of symptoms before treatment. have found that, in patients who fail to respond to more arbitrary therapy, bacteriological cure can be achieved by treatment based on effective serum levels of antibiotic. In particular, back-titration of the antimicrobial activity of the patient's serum against his own organism (Schlichter and MacLean, 1947) has been found useful in monitoring treatment.

Streptococci were the infecting organism in the majority of cases as in other reports (Cates and Christie, 1951; Lerner and Weinstein, 1966), but the type of organism within the group has altered. In the past Strep. viridans accounted for nearly all, but in proven cases of subacute bacterial endocarditis (Group I), its incidence was 45 per cent. Conversely, non-haemolytic and micro-aerophilic organisms are much more common. This difference has been recorded in other series (Lerner and Weinstein, 1966), but it probably represents case selection rather than a true change in the disease. Cates and Christie (1951) were able to record the true incidence as, at that time, virtually every case would be referred to their centres for treatment.

Staph. aureus was the infecting organism in 8 cases (12\%), and 6 of these appeared in Group III. Two cases of endocarditis following cardiac surgery were included, and provided examples of the unusual organisms which may be found under these circumstances. Staph. albus was isolated in blood culture 10 days after operation in one case (Quinn and Cox, 1964), and fungal elements suggestive of candida were seen at necropsy one year after aortic valve replacement in the second (Soler-Bechara et al., 1964).

The problem of negative blood cultures in bacterial endocarditis became apparent as soon as a cure was possible (Cates and Christie, 1951). The percentage recorded in different series varies with the diagnostic criteria used, but there are undoubted cases where blood culture fails to isolate the causative organism. Unusual organisms such as Brucella, Listeria, and Rickettsia have been isolated, and in one case L forms of Strep. faecalis were incriminated (Hudson, 1957; Mattman and Mattman, 1965; Ferguson, Craik, and Grist, 1962; Hoeprich and Chernoff, 1955). Failure to provide specialized growth requirements may account for some negative cultures. The prior use of antibiotics or the presence of infection for prolonged periods may also result in sterile cultures, as organisms are no longer released into the blood stream.

Ages of patients ranged from 4 weeks to 92 years and 68 per cent were over the age of 40 years. Bacterial endocarditis is uncommon in children, but in the past decade it has tended to attack a higher percentage of patients over 40 years (Hughes 
and Gauld, 1966). Some degree of mitral incompetence is found in a high proportion of patients with bacterial endocarditis, which is extremely rare in pure mitral stenosis. Mitral incompetence is more common in male patients (Wood, 1956) and this may account for the preponderance of patients with endocarditis. The commonest congenital abnormalities were ventricular septal defects and aortic stenosis.

Rodbard (1963) showed that at the base of a high pressure jet of blood the endocardium would be subject to a lower pressure than normal, and suggested that its nutrition would, therefore, be impaired. Mitral incompetence, aortic stenosis, and ventricular septal defect all involve a high pressure jet of blood passing into a lower pressure chamber, and this haemodynamic feature may account for their frequency in cases of subacute bacterial endocarditis. Arteriosclerotic changes may lead to nodule formation on the valve cusps, which in 3 patients acted as a focus for infection (Lichtman and Master, 1949).

Cases of acute bacterial endocarditis (Table II) are documented, but are a separate condition from subacute bacterial endocarditis. Often there is no underlying cardiac disease, especially when Staph. aureus is the infecting organism (Morgan and Bland, 1959). In many, diminished host resistance, such as from leukaemia or carcinomatosis, leads to septicaemia, and the heart valves are involved incidentally.

The clinical signs and symptoms of bacterial endocarditis have not altered in the 20 years since Cates and Christie's large series (1951). Fever and malaise were prominent, recurrent fevers with symptomless or apyrexial intervals occurred in 7 patients, and this feature may lead to difficulty in diagnosis (Wedgwood, 1955). In patients over the age of 65 years fever was not prominent (Jackson and Allison, 1961), and this also may cause the condition to be unsuspected, and contribute to the worse prognosis in this group.

The findings on physical examination reflect, to some extent, the duration of the illness. Splenomegaly is evidence of chronic disease and is found more commonly in subacute (Groups I and II) than acute endocarditis (Group III). Hepatomegaly was a frequent finding, and was not necessarily associated with signs of heart failure. Clubbing was present in a third of our patients, contrasting with a lower incidence reported recently (Lerner and Weinstein, 1966).

Coronary emboli were assumed to have caused infarction with the development of $Q$ waves in 7 patients, though coronary artery disease may have played a part in the electrocardiographic changes.
In other series the presence of myocardial microemboli at necropsy is relatively common (Brunson, 1953; Wenger and Bauer, 1958; Menzies, 1961). Myocardial damage from coronary emboli, or from pre-existing ischaemic heart disease in the elderly, can be expected to contribute to the development of heart failure, and therefore to the mortality of bacterial endocarditis. In rheumatic heart disease the myocardium is involved as well as the valves, whereas in most congenital lesions the myocardium is healthy. Again the myocardial factor plays a decisive part in determining prognosis.

Microscopical haematuria without clinical episodes of overt renal embolism was found in virtually all our cases of subacute bacterial endocarditis when a centrifuged deposit of fresh urine was examined. The incidence of haematuria found is the highest recorded, and in our cases the presence of red blood cells in the urine is a cardinal feature of the disease. Failure to demonstrate microscopical haematuria may occur if the urine is not fresh or if a centrifuged deposit is not examined.

The majority of patients with subacute bacterial endocarditis were in sinus rhythm. Mild mitral incompetence frequently was the underlying cardiac lesion, and infection occurs at a stage in its natural history when fibrillation is rare. Similarly in aortic stenosis or ventricular septal defects sinus rhythm is usual. The electrocardiographic changes due to coronary embolism have been discussed. Transient episodes of bundle-branch block were noted in 2 patients and may indicate oedema of the conducting tissues.

The mortality in this series shows little change from that recorded 20 years ago, despite the larger number of antibiotics available. This result is not, however, due to failure to effect bacteriological cure, but to the unrepresentative nature of the series, in that it includes older patients and patients referred from elsewhere who had undergone courses of treatment. It is likely that the initial state of the myocardium is of prime importance, and that if the heart is already damaged by coronary arteriosclerosis or the rheumatic process itself, any further stress from coronary emboli or increasing valvar incompetence may prove fatal.

\section{SUMMARY}

Ninety-three cases of bacterial endocarditis seen from 1956 to 1965 have been analysed, and an older age-group than in the past was found to be affected. By achieving levels of antibiotic that are bactericidal to the isolated infecting organism, bacterial cure is almost always possible, but mortality remains at $\mathbf{2 0}$ per cent. The initial state of the myocardium is of 
prime importance in determining this mortality, prognosis being worse in the elderly, in those with arteriosclerosis, and in those with rheumatic myocardial damage.

We gratefully acknowledge our indebtedness to the consultant staff for allowing us to study the notes of patients under their care, and to Professor L. P. Garrod who was bacteriologist to the hospital during the first part of this survey.

\section{REFERENCES}

Brunson, J. G. (1953). Coronary embolism in bacterial endocarditis. Amer. F. Path., 29, 689.

Cates, J. E., and Christie, R. V. (1951). Subacute bacterial endocarditis. Quart. F. Med., n.s. 20, 93.

Ferguson, I. C., Craik, J. E., and Grist, N. R. (1962). Clinical, virological, and pathological findings in a fatal case of $Q$ fever endocarditis. F. clin. Path., 15, 235.

Havard, C. W. H., Garrod, L. P., and Waterworth, P. M (1959). Deaf or dead? A case of subacute bacterial endocarditis treated with penicillin and neomycin. Brit. med. $\mathcal{F}$., 1, 688.

Hoeprich, P. D., and Chernoff, H. M. (1955). Subacute bacterial endocarditis due to Listeria monocytogenes. Amer. F. Med., 19, 488.

Hudson, R. A. (1957). Brucella abortus endocarditis. A case. Circulation, 16, 411

Hughes, P., and Gauld, W. R. (1966). Bacterial endocarditis: a changing disease. Quart. F. Med., n.s. 35, 511.

Jackson, J. F., and Allison, F. (1961). Bacterial endocarditis. Sth. med. F. (Bgham, Ala.), 54, 1331.
Lerner, P. I., and Weinstein, L. (1966). Infective endocarditis in the antibiotic era. New Engl. F. Med., 274, 199.

Lichtman, P., and Master, A. M. (1949). The incidence of valvular heart disease in people over fifty and penicillin prophylaxis of bacterial endocarditis. N.Y. St.F. Med., 49, 1693.

Mattman, K. H., and Mattman, P. E. (1965). L forms of streptococcus fecalis in septicemia. Arch. intern. Med., 115, 315.

Menzies, C. J. G. (1961). Coronary embolism with infarction in bacterial endocarditis. Brit. Heart $\mathcal{F}$., 23, 464.

Morgan, W. L., and Bland, E. F. (1959). Bacterial endocarditis in the antibiotic era, with special reference to the later complications. Circulation, 19, 753.

Quinn, E. L., and Cox, F. (1964). Staphylococcus albus (epidermidis) endocarditis: report of 16 cases seen between 1953 and 1962. In Antimicrobial Agents and Chemotherapy-1963. Proc. 3rd Conf., p. 635. Ed. by J. C. Sylvester. American Society for Microbiology, Ann Arbor, Michigan.

Rodbard, S. (1963). Blood velocity and endocarditis. Circulation, 27, 18.

Schlichter, J. G., and MacLean, H. (1947). A method of determining the effective therapeutic level in the treatment of subacute bacterial endocarditis with penicillin: a preliminary report. Amer. Heart f., 34, 209.

Soler-Bechara, J., Soscia, J. L., Kennedy, R. J., and Grace, W. J. (1964). Candida endocarditis. Amer.f. Cardiol., 13, 820.

Wedgwood, J. (1955). Early diagnosis of subacute bacterial endocarditis. Lancet, 2, 1058.

Wenger, N. K., and Bauer, S. (1958). Coronary embolism: review of the literature and presentation of 15 cases. Amer. F. Med., 25, 549.

Wood, P. (1956). Diseases of the Heart and Circulation, 2nd ed. Eyre and Spottiswoode, London. 